\title{
The Effect of The Covid-19 Pandemic on Employee Work Productivity at The Green Port Terminal
}

\author{
Nugroho Dwi Priyohadi ${ }^{1}$, Edy Priyanto ${ }^{2}$, Nur Widyawati ${ }^{3}$, Mudayat ${ }^{4}$, Yulian Andi \\ Setiawan $^{5}$ \\ Faculty of Administration and Management Barunawati Surabaya Indonesia ${ }^{12345}$
}

\{nugroho.dp@stiamak.ac.id ${ }^{1}$ \}

\begin{abstract}
The formulation of the problem in this study is whether the covid-19 pandemic affects the work productivity of employees at the Green Port Terminal. The sample in this study were 80 employees of the Green Port terminal. The data analysis technique used multiple linear regression analysis. The results of the analysis, it can be said that (1) Physical distancing (X1) has a significant relationship to work productivity (Y), namely if physical distancing is applied in the company, productivity will increase. (2) work from home (X2) has a significant relationship to work productivity (Y), This means that if work from home has been regulated by the company and employees carry out well, then work productivity will increase. (3) Physical distancing and work from home have a significant influence on employee work productivity, meaning that if physical distancing and work from home have been regulated by the company and obeyed by employees, they will be able to break the Covid-19 virus chain and will also affect work productivity. employee.
\end{abstract}

Keywords: Physical distancing, work from home and work productivity.

\section{Preliminary}

Given the role of humans in the organization is very important, it is necessary to have good cooperation in implementing a company. In order to increase company productivity. The rapid development of the business world at this time causes so many problems that must be faced, especially aspects of human resources as the executor of the company's production activities, where aspects of human resources are essentially the main role for companies to carry out company work activities as well as a means to activities in the future. The aspect of human resources in the company plays an important role, namely as one of the benchmarks for the level of employee productivity in a company, but at the beginning of 2020 there was a disaster that shocked the world, namely being shocked by the corona virus outbreak (Covid-19) which infected almost the whole world. Countries in the world.

Where Covid-19 was discovered and discovered in Wuhan, China in December 2019 and began to spread to various parts of the world including Indonesia in March 2020. At first this virus was known to first appear in the animal market and seafood market in the city of Wuhan.

The number of cases continues to grow over time until medical workers are infected with the corona virus. Even the world seems to place the Covid-19 virus as the main and biggest problem that must be immediately addressed and resolved. The process of the development of the Covid-19 virus and its handling, in addition to causing social changes, a decrease in people's income due to the Covid-19 virus, and changes in various lives that cause anxiety and fear in 
the community in the context of overcoming and handling what the government has done, but Indonesia is still considered low. in the Covid-19 test.

The government is one of the actors who has taken various ways so that the handling of cases of the Covid-19 virus can be overcome, prevention and handling in the early days of its spread, the government has begun to tighten entrances to Indonesia at many points such as airports or terminal ports. Efforts made by the government to prevent the spread of the Covid19 virus are deemed not good enough, seen from the increasing number of positive cases and the number of deaths caused by the Covid-19 virus. What the government can do in accelerating the handling of Covid-19 is to carry out investigations and services carried out on people who are exposed or Efforts who have symptoms of Covid-19 infection so that the spread of the virus can be focused and carried out.

Another important thing for the government is efforts to control the prices of tools, drugs, and medical needs needed by health workers and the public in preventing Covid-19. The increasing number of patients caused by the Covid-19 virus has made the Indonesian government issue various solutions and one of them is to promote the Social Movement away or visit social media and people usually call it home. This is done to be able to inhibit the spread of the Covid-19 virus by reducing the chain breaker of the Covid-19 virus where a person needs to maintain a safe distance from other humans at least 1 meter, and not to make direct contact with other people.

Considering the current urgency, the acceleration of handling Covid-19 must be implemented immediately so that PSBB must also be carried out immediately based on Law No. 6 of 2018 concerning health, there are several options that can be taken, such as PSBB, improvements can be made through repairing the area of the house or in the hospital. In addition, the government issued PP No. 21 of 2020 regarding the PSBB policy (Large-Scale Social Restrictions) which is the government's strategy to prevent the spread of the Covid-19 virus, meanwhile according to the Indonesian Ministry of Health (Kemenkes), PSBB does not completely limit all community activities This only applies to certain activities in an area infected with the Covid-19 virus. Many schools and universities were closed by the government in order to break the ropes of the spread of the virus by studying and working at home, limiting religious activities, transportation sports, public place activities and closing the workplace and special activities related to security aspects and also related to logistics. (Ministry of Health, 2020).

Changes in social conditions that occur suddenly can certainly make people shocked and uncomfortable, both in individuals and families. By enacting this PSBB, of course, all people will stay at home and gather with their families to do all activities from home with their families. The productivity of individuals and families will certainly change drastically with these new conditions. Therefore, in the context of the study discussing work and family productivity in the implementation of PSBB in several areas during the Covid-19 period.

It needs to be redeveloped to see the ability of individuals and families to perform work productivity at home during the PSBB activity period. Based on the background above, the author gives the title of this research with the title " The Effect of The Covid-19 Pandemic on Employee Work Productivity At The Green Port Terminal".

Based on the preliminary above, the formulation of the problem in this study can be formulated as follows:

1. Does physical distancing have an effect on employee work productivity?

2. Does work from home have an effect on employee productivity?

3. Do physical distancing and work from home have an effect on employee productivity? 


\section{Basic Theory}

\section{Work productivity}

Work productivity is the ability to get the maximum benefit from the available facilities and infrastructure by producing optimal output, if possible maximally (Siagnia 2002). Sources of work productivity are humans as workers, both individually and in groups, who are looking for ways to increase their productivity at work, especially by increasing the quality of productivity in carrying out their work.

Sources of work productivity are:

a. Use of Mind

Work productivity is said to be high if it obtains maximum results using an easy way, and does not require a lot of complicated and difficult thoughts in doing work;

b. Use of Time

Productivity in terms of time, with regard to how fast or slow a job is to achieve a result at work;

c. Room Use

A job is said to be productive if it uses a reasonable size space, so it does not require much mobility;

d. Use of Materials and Money

A job is said to be productive, if the use of raw materials and other equipment is not too much wasted and the price is not too expensive, without reducing the quality of the results achieved, and the work is said to be economical (Sedarmayanti, 2004).

\section{Physical distancing}

Social distancing is reducing the number of activities outside the home and interaction with other people, reducing direct face-to-face contact, which makes it possible to transmit the virus to others.

Social distancing movements that can be carried out both in public places, at work, and at home:

1. Social distancing in public places:

a. Avoiding public transportation, use public transportation that is quiet by maintaining a distance of at least 1 meter from other passengers;

b. Do not eat in public places such as cafes, restaurants or mall food courts;

c. Do not travel either domestically or abroad;

d. Not visiting grocery stores during off-peak hours;

e. Don't go to the bustling center of perl;

f. Not traveling abroad for a while until it is completely safe.

2. Social distancing at home:

a. Limit the visits to neighbors homes and limit visits to other people's homes;

b. Temporarily suspend social gatherings, reunions or gatherings of neighbors;

c. Meanwhile, let the children play without friends and only play inside the house;

d. If there is an elderly person in the household, limit social contact, because in this case age is very vulnerable to contracting various kinds of viruses because the body's resistance is not the same as young people

e. do useful activities without involving many people;

f. If one of the family members has a fever, cold or cough, try not to share eating utensils and sleep together. 
3. Social distancing in the office/workplace:

a. Avoid meetings with many people, use video calls, video conferencing, online conversations via chat or telephone;

b. Inevitable face-to-face meetings, keeping distance, limited time, not sitting close and avoiding physical contact such as shaking hands;

c. Try to bring your own food supplies from home;

d. Do not gather in the workspace, kitchen, photocopying area and where we usually socialize.

\section{Work from home}

Work from home is a term for working remotely, more precisely working from home. So workers do not need to come to the office face to face with other workers. Working from home will provide flexible time for workers to provide a balance of life for employees.

1. The Advantages of Working From Home

a. Operational costs decreased;

b. More flexible in working;

c. Decreased stress levels;

d. Closer to family.

2. Disadvantages of Working From Home

a. Difficult to monitor workers;

b. Many work interruptions Not every work done from home can run smoothly;

c. Miscommunication;

d. Data security is one of the issues that need to be considered when working from home;

e. Home operating costs increase.

Framework and Hypotheses

From the description that has been described above, the framework and hypotheses in this study are as follows:

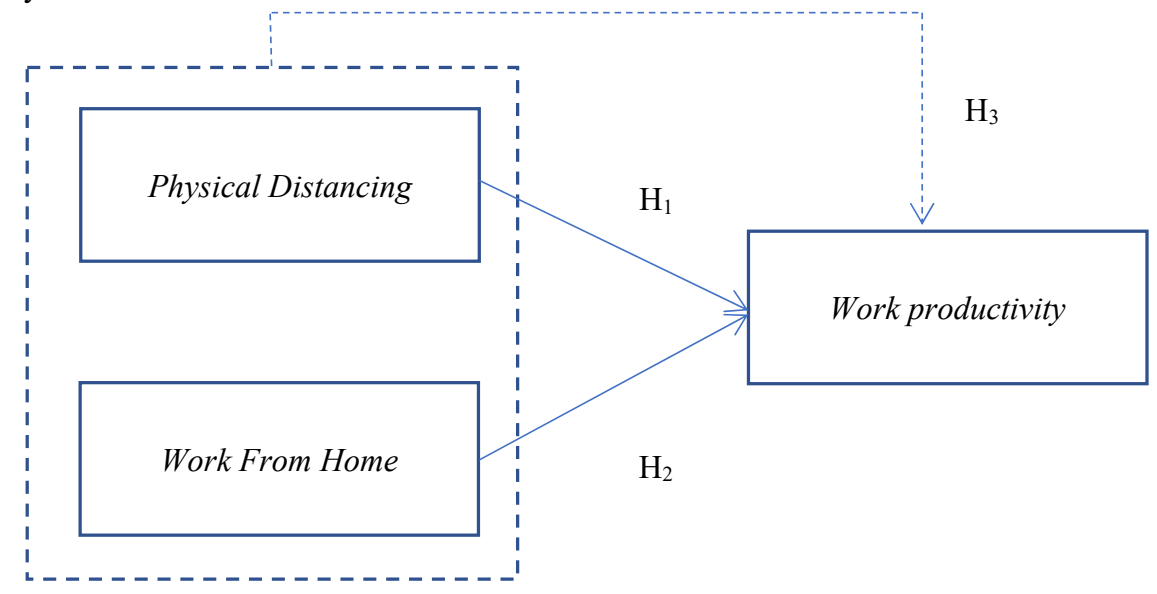

Fig 1. Framework

Source: Primary Processed Data 
H1 = It is suspected that Physical Distancing has a significant relationship to employee work productivity.

$\mathrm{H} 2$ = It is suspected that Work From Home has a significant relationship to employee work productivity.

H3 = It is suspected that Physical Distancing and Work From Home have a significant relationship to employee work productivity.

\section{Metodhology}

Every scientific work made must be adapted to the research methodology. The method in this study uses quantitative research methods. Methods of data collection using a questionnaire with respondents as many as 80 employees of the green port terminal. The analysis technique in this study uses multiple linear regression analysis.

The variables in this study are:

Independent variables:

1. Physical distance (X1)

2. Work from home (X2)

Dependent variable : Work productivity $(\mathrm{Y})$

Table 1. Validity Test Results for Each Variable

\begin{tabular}{cccc}
\hline Variables & r count & r Table & Conclusion \\
\hline $\begin{array}{c}\text { Physical Distancing } \\
\text { (X1) }\end{array}$ & & & \\
Statement 1 & 0,770 & 0,220 & Valid \\
Statement 2 & 0,556 & 0,220 & Valid \\
Statement 3 & 0,776 & 0,220 & Valid \\
Statement 4 & 0,761 & 0,220 & Valid \\
Wrok From Home (X2) & & & \\
Statement 1 & 0,795 & 0,220 & Valid \\
Statement 2 & 0,415 & 0,220 & Valid \\
Statement 3 & 0,779 & 0,220 & Valid \\
Statement 4 & 0,818 & 0,220 & Valid \\
Produktivitas Kerja(Y) & & & \\
Statement 1 & 0,626 & 0,220 & Valid \\
Statement 2 & 0,594 & 0,220 & Valid \\
Statement 3 & 0,675 & 0,220 & Valid \\
Statement 4 & 0,863 & 0,220 & Valid \\
Statement 5 & 0,843 & 0,220 & valid \\
\hline
\end{tabular}

From table.1, it can be seen that each variable from the statement is valid because all items have r-count $>$ r-table $(0.220)$.

Table 2. Reliability Test Results

\begin{tabular}{llll}
\hline Variable & Cronbach's Alpha & Kriteria & Keterangan \\
\hline Physical Distancing (X1) & 0,684 & 0,6 & Reliable \\
Work From Home (X2) & 0,651 & 0,6 & Reliable \\
Work productivity (Y) & 0,765 & 0,6 & Reliable \\
\hline
\end{tabular}


Table 2, it is known that Cronbach's Alpha value of Physical Distancing (X1), Work From Home (X2), and Based on productivity (Y) variables is greater than 0.6 so it can be said that the data is reliable, which means that the questionnaire can be used in research.

Normal P-P Plot of Regression Standardized Residual

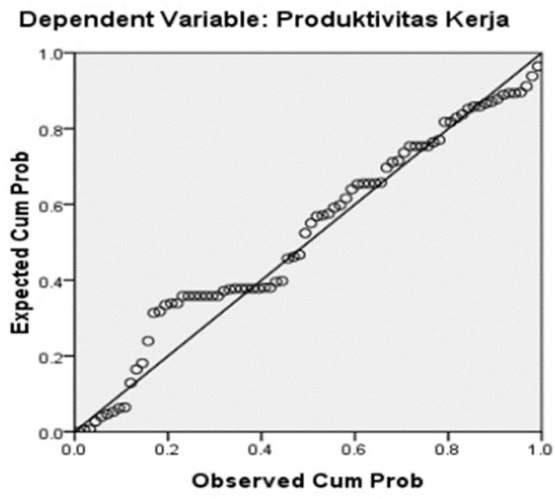

Fig 2. Normality Test Results

Source: primary data processed with SPSS (2021)

The results of the normality test in Picture 2 show that the spread of data (points) on the diagonal axis of the graph does not spread far from the diagonal line or follows the direction of the diagonal line, so the regression model fulfills the assumption of normality.

Scatterplot

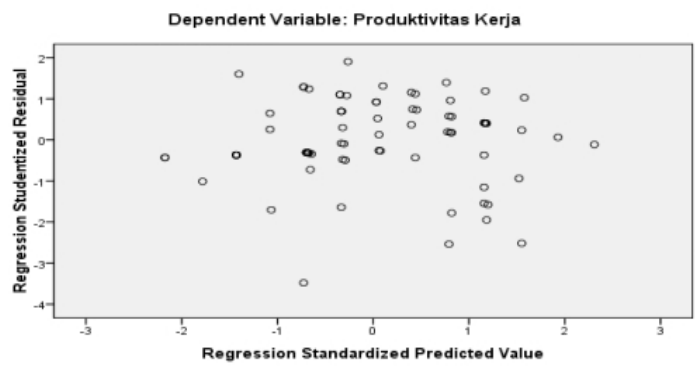

Fig 3. Heteroscedasticity Test Results

Source: primary data processed with SPSS (2021)

The results of the heteroscedasticity test in Picture 3 above show that the scatterplot does not form a certain pattern and the points spread above and below the number 0 on the $\mathrm{Y}$ axis, so there is no heteroscedasticity. 
Table 3. Multicollinearity Test Results

\begin{tabular}{llll}
\hline \multirow{2}{*}{ Model } & \multicolumn{2}{l}{ Collinearity Statistics } & \multirow{2}{*}{ Description } \\
\cline { 2 - 3 } & Tolerance & VIF & \\
\hline X1 & 0,991 & 1,009 & Multicollinearity does not occur \\
X2 & 0,991 & 1,009 & Multicollinearity does not occur \\
\hline & \multicolumn{3}{l}{ Source: primary data processed with SPSS (2021) }
\end{tabular}

Based on table 4.2 above, the tolerance value for the Physical distancing (X1) and work from home (X2) variables is 0.991 , which is greater than 0.10 . Meanwhile, the VIF value of the Physical distancing variable (X1) and working from home (X2), which is 1,009, is smaller than 10,000 so that it can guarantee that multicollinearity does not occur. Regression analysis is used to determine the extent of the relationship between the independent variables to the specified variables.

Based on regression analysis using SPSS, the following results were obtained:

Table 4. Results of Multiple Linear Regression Analysis

\begin{tabular}{lllll}
\hline Variable & B & T Count & Sig. & Description \\
\hline (Constant) & 5.569 & 1.827 & 0.072 & - \\
Physical Distancing (X1) & 0.424 & 2.940 & 0.004 & Significant \\
Work From Home (X2) & 0.440 & 2.923 & 0.005 & Significant \\
F Count & & 7.861 & 0.001 & Significant \\
R & & 0.512 & & \\
Adjusted R Square & & 0.148 & & \\
\hline
\end{tabular}

Source: primary data processed with SPSS (2021)

Based on table 4.3 above, the equation is as follows :

$$
\begin{aligned}
& \mathrm{Y}=\alpha+\beta_{1} \mathrm{X}_{1}+\beta_{2} \mathrm{X}_{2}+\mathrm{e} \\
& \mathrm{Y}=5,569+0,424 \mathrm{X}_{1}+0,440 \mathrm{X}_{2}+\mathrm{e}
\end{aligned}
$$

Information :

$\mathrm{Y}=$ Work Productivity

$\alpha=$ Constant

$\beta 1=$ Physical distancing regression coefficient

$\beta 2=$ Work from home regression coefficient

$\mathrm{X} 1=$ physical distance

$\mathrm{X} 2$ = work from home

$\mathrm{e}=$ Estimation error

From the results of multiple linear regression testing there are equations that show the coefficients of the two independent variables $(\beta 1, \beta 2)$ are positive $(+)$ This means that if the Physical distancing variable (X1), work from home (X2) is achieved, work productivity will increase. increases, and vice versa if it is negative (-) this means that if the Physical distancing variable (X1), work from home (X2) is fulfilled, work productivity will decrease. From table 
4.3 it is known that physical distancing (X1) and work from home (X2) have a significant effect on work productivity (Y) either partially or simultaneously (simultaneously).

The results from table 4.3 also show that the $\mathrm{R}$ value of 0.512 indicates that the relationship between work productivity with Physical Distancing (X1) and work from home (X2) variables is strong, because the $\mathrm{R}$ value is more than 0.5 , it can be said to be strongly correlated. From the calculation of the coefficient of multiple determination with the help of SPSS, it is known that the value of the coefficient of multiple determination of Adjusted R Square is 0.148 or $14.8 \%$. This value indicates that work productivity can be explained by Physical Distancing (X1) and work from home (X2) variables, while the remaining $85.2 \%$ is explained by other variables not examined in this study.

\section{Discussion}

a. Relationship of Physical Distancing (X1) to Work Productivity (Y)

The Physical Distancing variable partially has a significant relationship to the work productivity variable. The results of the $t$ test with SPSS which are presented in table 4.3 above, it is known that the Physical Distancing variable (X1) has a significant relationship to productivity based on work (Y). This can be proven by the results of the t count of 2,940 which is greater than the t table of 1,994 with a significance level of 0.004 less than 0.05 . So it can be said that the Physical Distancing variable has a significant relationship to the work productivity variable partially.

In accordance with the conditions on the ground, it was observed that the Green Port Terminal reduces face-to-face meetings with other employees, using video calls, video conferences and other online conversations to coordinate in accordance with government recommendations. With the convenience and sophistication of communication tools, employees can still work well so as to increase work productivity.

b. Relationship Working From Home (X2) With Work Productivity (Y)

The Work From Home variable partially has a significant relationship to the work productivity variable. the test results based on SPSS presented in table 4.3 above, it is known that the Work From Home (X2) variable has a significant relationship to work productivity (Y). This can be proven by the t-count result of 2.923 which is greater than the t-table of 1.994 with a significance level of 0.005 less than 0.05 . So, it can be said that the Work From Home variable has a significant effect on the work productivity variable partially.

In accordance with the conditions in the field, it is known that Work From Home can be more flexible in working even though it is difficult to monitor because not all work in Green Terminals can be done at home.

c. The Relationship between Physical Distancing (X1) and Work From Home (X2) on Work

Productivity

It can be seen that Physical Distancing (X1) and Work From Home (X2) together (simultaneously) have a significant relationship to the dependent variable, namely work productivity ( $\mathrm{Y}$ ). This is evidenced by the significant value of $\mathrm{F}$ arithmetic 7.861 greater than $\mathrm{F}$ table 3.11 and a significance level of 0.001 smaller than alpha 0.05 . Physical Distancing and Work From Home will work well if employees seriously implement company policies and health protocol protocols that have been regulated by the government. 


\section{Conclusion}

Based on the results of the study using multiple linear regression analysis, the researchers concluded: Physical distancing (X1) has a significant relationship to work productivity (Y), meaning that if physical distancing is applied in the company, productivity will increase. Work from home (X2) has a significant relationship to work productivity (Y), meaning that if work from home has been regulated by the company and employees carry out well, work productivity will increase. Physical distancing and work from home have a significant effect on employee work productivity, meaning that if physical distancing and work from home have been regulated by the company and obeyed by employees, they will be able to break the Covid-19 virus chain and will also affect employee work productivity.

\section{References}

[1] Damayanti. 2005. Pengukuran produktivitas kerja. Semarang : Universitas Negeri Semarang

[2] Dharma 1995. Pengukuran Produktivitas Kerja. Jakarta: PT Erlangga.

[3] Ghozali, Imam. 2012. Aplikasi Analisis Multivariate dengan Program SPSS, Semarang: Universitas Diponegoro.

[4] Komaruddin. 2010. Sumber Daya Manusia dan Produktivitas Kerja, Jakarta: Bumi Aksara.

[5] Muchdarsyah. 2009. Produktivitas Apa dan Bagaimana, edisi kedelapan, Jakarta: Bumi Aksara.

[6] Ramayani. 2004. Pengertian Produktivitas Kerja, Jakarta: PT Erlangga.

[7] Siagian. 2002. Pengertian Produktivitas Kerja, Jakarta: Bumi Aksara.

[8] Sedarmayanti. 2004. Sumber Daya Manusia dan Produktivitas Kerja, edisi ketiga, Bandung: Mandar Maju.

[9] Sutrisno. 2009. Faktor-faktor yang mempengaruhi produktivitas kerja, Bandung: Alfabet.

[10] Sugiyono. 2011. Metodologi Penelitian Kuantitatif, Kualitatif, dan R\&D, Bandung: Alfabeta.

[11] Surat Kementrian Tenaga Kerja Nomor. 5/193/A5.02.02/III/2020 tentang Kesiapsiagaan dalam menghadapi penyebaran Covid-19 di tempat kerja

[12] Surat Edaran Kementrian Tenaga Kerja No. M/3/HK.04/III/2020 Tentang Perlindungan Pekerja/buruh dan Kelangsungan usaha dalam Rangka Pencegahan dan Penanggulangan Covid-19

[13] https://www.who.int/indonesia/news/novel-coronavirus/qa-for-public

[14] https://www.pelindo.co.id

[15] https://www.cdc.gov/coronavirus/2019-ncov/summary.html

[16] www.teluklamong.co.id 